To appear in The Origin and Evolution of Languages: Approaches, Models, Paradigms, ed. by Bernard Laks, Serge Cleuziou, Jean-

Paul Demoule, \& Pierre Encrevé. London: Equinox. 2007

\title{
WHAT DO CREOLES AND PIDGINS TELL US ABOUT THE EVOLUTION OF LANGUAGE???
}

\author{
Salikoko S. Mufwene \\ University of Chicago
}

\section{Introduction}

Bickerton (1990) and Givón (1998) claim that the development of creoles and pidgins can provide us with insights about how language has evolved in mankind. This extrapolation has been encouraged by the position that creoles have typically been developed by children from erstwhile pidgins, transforming them from proto-languages (with just embryonic grammars) to full-fledged languages (endowed with complex syntactic systems). ${ }^{1}$ Underlying this position is the unarticulated assumption that

\footnotetext{
${ }^{1}$ I am grateful to Michel DeGraff, Alison Irvine, and Bertram Malle for feedback on earlier versions of this essay. All the remaining shortcomings are my sole responsibility.

${ }^{2}$ The order of the terms creoles and pidgins is deliberately reversed in the title of this chapter and in the whole discussion to reflect the contention that creoles have not evolved from pidgin ancestors (Alleyne 1971; Chaudenson 1992, 2001; Mufwene 1997, 2001). There is no compelling evidence in support of such an evolutionary trajectory, at least not among creoles of the New
} 
systems evolve from simpler to more complex structures. It has mattered very little that over the past few millennia the inflectional systems of many Indo-European languages have likewise evolved from rich to poor ones, and their syntactic structures into increasingly analytical ones in which the position of syntactic constituents is critical to determining their functions. This is as true of the gradual development of the Romance languages from Latin as of English from Old English.

I argue that what little the development of creoles and pidgins tells us about the evolution of language in mankind is definitely not what has been claimed in the literature. It has to do with competition and selection during the evolution, with how gradual the process was, and with how communal norms arise. The histories of the development of creoles and pidgins in, respectively, the European plantation and trade colonies of the 17th-19th centuries present nothing that comes close to replicating the evolutionary conditions that led to the emergence of modern language. Nor are there any conceivable parallels between, on the one hand, the early hominids' brains and minds that produced the proto-languages posited by Bickerton (1990, 2000) and Givón (1998) and, on the other, those of both the modern adults who produced (incipient) pidgins and the modern children who produce child

World and the Indian Ocean. What is suggested by the socio-economic histories of the territories where these language varieties have developed is an interesting geographical division of labor, which situates pidgins typically in former trade colonies and creoles in plantation settlement colonies (Mufwene 2001). More on this below. 
language, even if one subscribes to the ontogeny-recapitulates-phylogeny thesis.

Givón (1998) certainly makes some correct observations regarding gradualness in the evolution of language, the coevolution of language and the cognitive infrastructure necessary to carry it, and the centrality or primacy of some aspects of language. These are precisely some of the hypotheses defended by $\mathrm{Li}(2002)$ and Slobin (2002), to which I also subscribe. Relying largely on my own longitudinal study of my daughter's child language (Mufwene 1999), I capitalize both on Tomasello's (2002) “cut and paste” model of language acquisition, which suggests that learners develop the grammars of their idiolects incrementally, and on Slobin's observation that the order in which child language develops is largely also influenced by the kinds of primary linguistic data to which the learners have been exposed. My arguments regarding creoles corroborate Slobin's other observation that where a full-fledged language is already in usage, children (at child language stage) are not the innovators of the new forms and structures that spread in the language of a population. However, I also agree with DeGraff (1999a, 1999b, to appear) that they contribute to the development of creoles qua communal systems by selecting some of the adults' innovations (often associated with substrate influence), just like any other features that become part of their idiolects, and will thus make them available to future learners. (See also Mufwene, to appear). 


\section{Why creoles have not developed from pidgins ${ }^{3}$}

Most of the arguments summarized below are intended to provide a notional, not so speculative, background to the discussions in the following sections. Space limitations dictate that I not repeat here demonstrations that are elaborated in Chaudenson (2001) and Mufwene (2001).

It is surprising that the pidgin-to-creole developmental scenario has hardly been disputed for almost a whole century, from Schuchardt (1914), Jespersen (1922), and Bloomfield (1933) to the present day. A simple look at the geographical distribution of our heuristic prototypes of creoles and pidgins — those lexified by European languages - suggests already that the alleged ancestor-to-descendant connection is tenuous. Most pidgins are concentrated on the Atlantic coast of the African mainland and on Pacific islands, whereas most creoles are concentrated on Atlantic and Indian Ocean islands (including places such as Cape Verde and São Tomé) and on the Atlantic coast of the Americas.

${ }^{3}$ Bickerton's notion of pidgins that bears on the present discussion is that they are grammarless, which justifies comparing them to the proto-linguistic ancestor of modern human languages. Among his central arguments is the inter-individual variation observable in them. There is yet no evidence that the idiolects they consist of are not internally systematic. Neither can we overlook the inter-idiolectal variation that obtains in any language or dialect community (Paul 1891). I will assume in the rest of this paper that Bickerton must have had incipient pidgins in mind. 


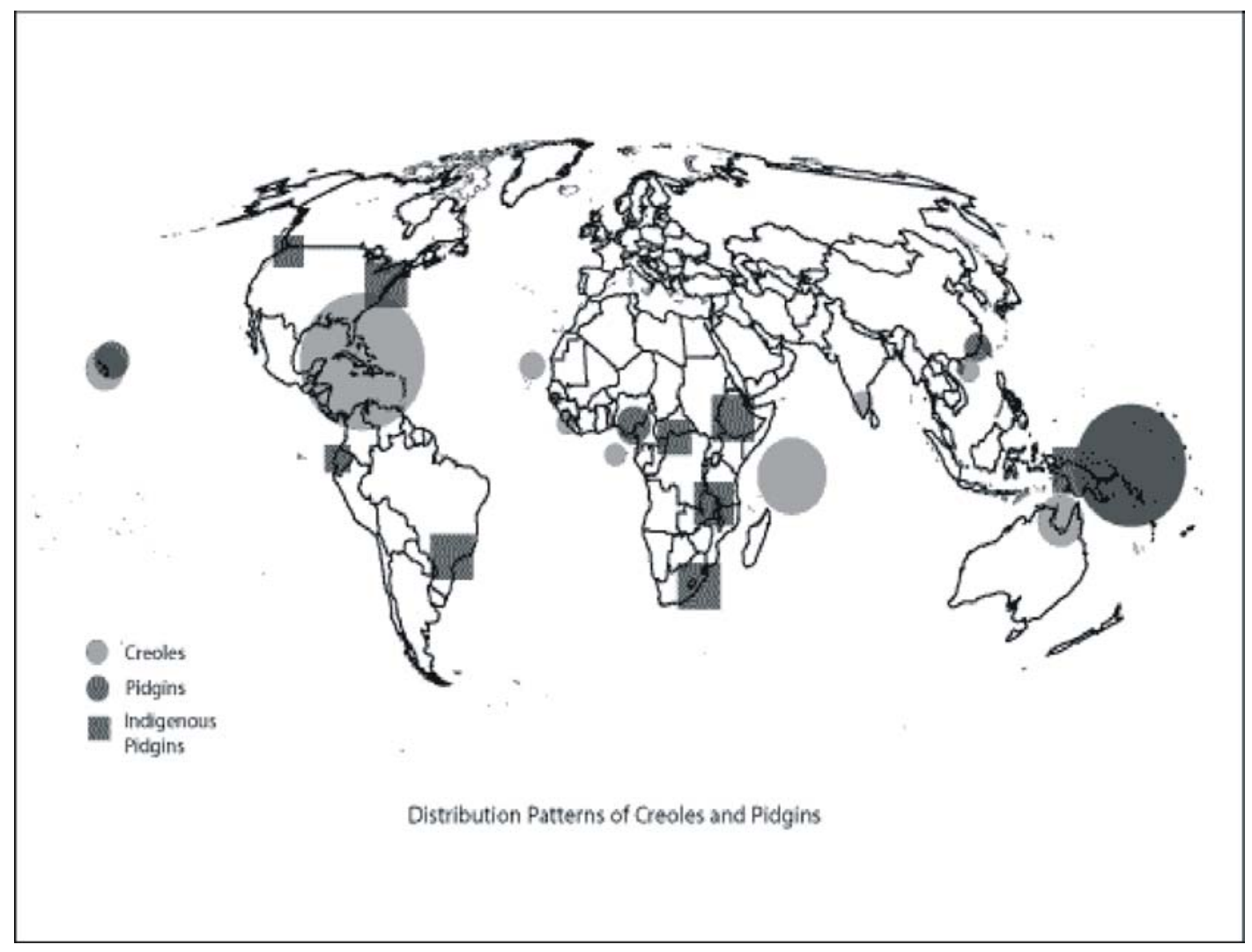


The European colonization of the coast of Africa and of the Pacific islands started on the trade model, ${ }^{4}$ characterized initially by egalitarian and sporadic contacts with the Natives, whose exposure to the European trade languages was limited. Rather than anything have to do inherently with adult L2-learning, the sporadicness of the contacts is the primary reason why incipient pidgins have been characterized as “broken." It is worth pointing out that the initial contacts of Europeans and the Natives depended on a handful of non-European interpreters, who spoke non-pidgin varieties. As the contacts increased, more and more non-Europeans who had no training and no access to interpreters would attempt to speak the trade language. As

\footnotetext{
${ }^{4}$ In Mufwene (2001, Chapter 1), I distinguish three different colonization styles since the
} $16^{\text {th }}$ century, which account partly for the different linguistic developments discussed in the main text. Only the third colonization style needs to be mentioned here, the exploitation colonies, which developed the $19^{\text {th }}$ century from trade colonies of Africa, Asia, and Pacific islands. Europeans came to them on short-term contracts, to work for companies headquartered in their metropoles or to administer them. European languages were (re-)introduced through the school system to form an elite class of indigenous colonial auxiliaries. In using them as lingua francas, the latter developed varieties identified as indigenized, for instance, Nigerian English (different from Nigerian Pidgin English)and African French, which are based on scholastic, rather than nonstandard or colloquial, models. The controlled, rather than naturalistic, mode of transmission associated with their emergence makes them rather irrelevant to the present discussion. 
the number of such speakers grew, the structures of the trade languages became more divergent from the relevant European vernaculars and apparently more "broken." 5 The direction of the divergence is similar to that of the basilectalization process associated with the emergence of creoles, as shown below.

On the other hand, as the pidgins' communicative functions increased (such as in the cities that emerged from erstwhile trade factories), these “contact varieties" became structurally more complex, and regularity of use gave them more stability. These additional characteristics changed them into what is known as expanded pidgins, like Tok Pisin and Nigerian Pidgin English, which for some speakers function also as vernaculars, rather than as lingua francas only. History suggests that children had no privileged role to play in this structural expansion (see, e.g., Mühlhäusler 1997), though they certainly helped vernacularize the varieties. The fact that some pidgins in Africa and the Pacific would develop later into vernaculars identified as expanded pidgins bears no consequence on Chaudenson's and my position on the development of creoles, as becomes obvious below.

Creoles have typically developed in plantation settlement colonies, in which nonEuropeans formed the majority of their respective populations (Chaudenson 2001, Mufwene 2001). Although some non-plantation settlement colonies, such as those of

${ }^{5}$ Bolton (2000, 2002) provides very informative accounts of the development of Chinese Pidgin English that is in agreement with the position submitted here. 
North America and Australia, also developed with European majorities that were non-native speakers of English or French (which count among the languages that produced “classic creoles and pidgins"), their new nonstandard vernaculars have not been identified as creoles. This is a distinction that has to do more with a social bias in genetic linguistics than with actual differences in the structural processes by which new creole and non-creole varieties of European languages have evolved outside Europe (Mufwene 2001). I submit that what the relevant colonial histories show is that contact has generally played a central role in recent language speciation and most likely also in earlier stages of language evolution of the past 10,000 years or so.

In any case, creoles developed in those settings where interactions between Europeans and non-Europeans were regular during the initial, homestead phase of the colonies. Communication in almost all cultural domains was then (intended) in the European language, since, on average, non-native speakers did not have anybody else to speak their own ethnic languages with. If one were the only nonEuropean in a homestead relatively isolated from others, there was nobody else to speak his/her language with. If there was another one in the homestead or in a neighboring one, he or she probably did not speak the same language. If they had a common language, they probably did not interact regularly enough to maintain and pass it on to children they could have had in different sexual relations. Or the children did not find the command of such non-European languages particularly 
advantageous to their daily lives. The earliest varieties commonly spoken and appropriated by non-Europeans were approximations of the European colonial languages forged in part by non-native European indentured servants. All locallyborn children from European and non-European parents who grew up in the same homestead and spent their days together while their parents were at work spoke alike, regardless of how their parents spoke the local vernacular (Chaudenson 1992, 2001). The experience of such children would not have been different from that of Black middle-class kids growing up in integrated neighborhoods in American cities today, whose linguistic features typically reflect those of the larger community rather those of their parents, especially if these are immigrants.

Among the non-Europeans, the local European language gradually evolved into a different variety during the plantation phase, after the population majorities consisted not only of non-Europeans but also of non-native speakers, thanks to rapid population turnovers and increases made possible by importations rather than by birth. Although segregation played a role in fostering the divergence of speech varieties of Europeans and non-Europeans, the increasing demographic dominance of non-native speakers among non-Europeans communicating primarily among themselves in the new vernacular also favored a greater role of nonEuropean substrate influence. ${ }^{6}$

\footnotetext{
${ }^{6}$ The reader should remember that non-plantation settlement colonies had similar beginnings,
} 
Bickerton (1988) agrees with part of the above position, as he admits that creoles did not develop from erstwhile pidgins and that their basilects developed later than their mesolects. The intimate living conditions shared by Europeans and nonEuropeans alike during the homestead phase of settlement colonies made no allowance for the development of pidgins as structurally reduced language varieties associated with sporadic contacts. As we rethink the colonial history of the New World in particular, it appears that the Europeans colonized it in two concurrent ways. All along the Atlantic coast and on its barrier islands - including the Caribbean, Bermuda, and the Bahamas — they developed settlement colonies on land which they gradually took away from the Native Americans. At the same time, the Europeans also developed trade relations with the Natives, before they eventually drove them westwards and into reservations and eventually absorbed large proportions of the survivors of this invasion into new, European-styled socioeconomic systems, especially since the $19^{\text {th }}$ century. Pidgins in the Americas developed from those originally sporadic trade contacts between Europeans and non-Europeans. We just must address the enigma of why "classic pidgins" in Africa and the Pacific developed from European languages but their counterparts in the

with small homesteads, although they depended more on European indentured than on African slave labor. As the colonies grew larger and admitted immigrants from European nations other than the metropole, dialect and language contact played an increasingly more significant role in the evolution of colonial vernaculars, especially as the populations became less segregated by nation of origin. 
Americas did from indigenous ones, for instance, Chinookan for Chinook Jargon, Delaware for Delaware Jargon, Choctaw for Mobilian Jargon, and Tupi for Lengua Geral. $^{7}$

Structural similarities between expanded pidgins and creoles reflect the fact that they were developed largely by linguistic adults interacting regularly among themselves, using materials from typologically related European and/or substrate languages to meet diverse and complex communicative needs, and thus needing complex grammatical structures. Substrate influence seems to have been greater in colonies that Chaudenson (1979-2001) identifies as endogenous and where there was relatively more ethnolinguistic homogeneity in the substrate population (Sankoff \& Brown 1976, Sankoff 1984, Mufwene 1986, Keesing 1988, Singler 1988). It was less significant in exogenous colonies (i.e., those where both Europeans and nonEuropeans had relocated, such as in the New World and in the Indian Ocean) and obviously where the pattern of population growth from the homestead to the

\footnotetext{
${ }^{7}$ Note that according to Keesing (1988), the birth place of Melanesian pidgins is not the plantations on which they have flourished. Rather, it is the whaling and trade ships on which some of the first plantation laborers had worked and spoken a proto-Melanesian Pidgin. This would account for structural similarities among Melanesian English pidgins, especially in those respects that distinguish them as a group from Atlantic creoles. However, Baker (1993) argues that a truer proto-Melanesian Pidgin would have evolved earlier in Australia, especially in Queensland, where several Melanesians had worked too. Moreover, Australia controlled much of that fishing and trade fleet in that part of the Pacific.
} 
plantation societies fostered gradual divergence from the relevant European language, contrary to the allegedly catastrophic kind of restructuring that has often been claimed (notably by Bickerton 1981, 1094, 1999).

The above observations are among the assumptions underlying my discussion below about whether or not the development of creoles and pidgins can inform our speculations about how language evolved in mankind. In sum, creoles did not evolve from erstwhile pidgins. Creoles developed independently from pidgins, the former in plantation settlement colonies and the latter in trade colonies. Both developed gradually, from closer approximations of the initial targets to varieties more and more different from them. They are creations no more of children exclusively than they are of adult L2-learners exclusively. Actually, substrate influence in creoles would be difficult to account for if the role of adult non-native speakers as carriers of xenolectal features were not factored in our hypotheses. The role of children in the development of creoles involved selecting some of those substrate features into their idiolects and making them available to future learners.

3. Why creoles were not made by children

Kegl \& McWhorter (1997), Kegl et al. (1999) and Goldin-Meadow (2002) argue convincingly that children could develop elaborate sign languages. The fact that, in the case of Nicaraguan Sign Language (NSL), the new system is largely a systematization of materials that were already available to the children in their community (Sengha \& 
Coppola 2001, Kegl et al. 1999, Morford 2002) reduces nothing in the important role that children played in elaborating a long-lasting communicative system. In this respect, they can very well be compared to our hominid ancestors at various stages of the evolution of mankind, who would develop a more elaborate and systematic communicative means from what had been used by the earlier generation of hominids. Goldin-Meadow's evidence can even be used to argue that systematicity did not develop because speakers/signers had to communicate with each other but because they had to be individually consistent (Mufwene 1989). Among the relevant questions at the population level are the following two: How do communal norms develop? Does the development of communal norms entail the elimination of inter-individual variation? The available evidence from child language and creoles militates for a negative answer to the second question. MacWhinney (2002:254) even observes that "we should not be surprised to find large individual differences in the neuronal basis of higher-level dynamic control of language.”

In any case, the evidence from home sign language and NSL are not comparable to those of the development of creoles or pidgins. More interesting about incipient pidgins is the fact that they represent simplifications, reductive developments of some sort, from full-fledged languages. Evolutionarily, they have evolved in the opposite direction of proto-Language, which started from non-linguistic means of communication. ${ }^{8}$ At best,

\footnotetext{
${ }^{8}$ This is more or less in the spirit of Comrie (2000) and Kihm (2002), who observe that the
} 
what they teach us about the evolution of language is that not all structural components of modern linguistic systems are as deeply entrenched. Those morphosyntactic components that survive the "break down," so to speak, that produces incipient pidgins may be the most deeply entrenched in the architecture of language. The same is true of these incipient varieties' heavy dependence on the pragmatic context for the interpretation of utterances, as highlighted by the language disorder cases discussed by MacWhinney (2002). The development of more complex structures would thus have streamlined the interpretation of utterances and reduced dependence on non-linguistic context.

MacWhinney (2002:250-251) also argues that the ability to use articulate sounds to communicate linguistically developed between 200,000 and 50,000 years ago, and thus brought the increase of brain size in hominids to its full communicative potential, such as to develop a larger lexicon and, later on, to combine words into larger strings. ${ }^{9}$ Interestingly, the phonemic systems of incipient pidgins reflect

makers of proto-language did not have an antecedent (proto-)language to derive materials from, although there must have been an earlier means of communication that would have paved the way for the evolution of the earliest linguistic systems. Jackendoff (2002) speculates that communication before proto-language must have consisted of one-'word’ signs, as among nonhuman primates. This still makes the case of creoles and pidgins, which developed from fully developed languages, quite different.

${ }^{9}$ Jackendoff (2002) comes close to this idea as he argues against "syntactocentrism” in favor of "parallel architecture” of phonology, syntax, and semantics. The evolutionary order he 
mostly interference from languages previously spoken by the speakers. They don't reveal the kind of "breakdown” evidenced by the morphosyntactic components, which dispenses with some lexical and grammatical categories. Thus incipient pidgins support the hypothesis that the ability to produce phonemic sounds is one of the most deeply entrenched components of spoken languages.

Regarding creoles, we must recall that it has all along been misguided to define creoles as nativized pidgins. Neither the geographical distribution of creoles and pidgins nor the respective socio-economic histories of the territories where creoles developed support this position. Assuming that contact has played a central role in the evolution of, say, Indo-European languages outside and within Europe, creoles developed by the same normal restructuring processes, although the role of language contact must have been made more obvious by the non-European composition of the populations appropriating the European languages (Mufwene 2001). Below, I adduce structural arguments against the position that creoles were made by children, although, in communities where adult L2-speakers and children use the same vernaculars, children produce utterances that apparently vary less in

\footnotetext{
suggests on page 238 seems intuitively less plausible than MacWhinney’s (2002) alternative, according to which syntax must have developed later than the aptitude to articulate sounds beyond vocalization (which made it possible to produce larger vocabularies) and the referential ability to use vocal symbols earlier than phonetic communication. For MacWhinney, the ability to form more words made it possible to convey more complex thoughts, which called for more complex syntax.
} 
their structures from one speaker to another (p.c., Givón, 11 June 2001). Senghas \& Coppola (2001) show that the signers exposed to NSL as children (below 10 years of age) sign more systematically, uniformly, and fluently than adults.

Children did indeed play a non-negligible role in the development of these new vernaculars, but it was not that of creating a grammar where their parents would presumably have failed. It is not true that incipient pidgins have no grammars, although these are internally variable. ${ }^{10}$ Rather than creating new grammars for the overall community, children participated in the development of creoles (not from erstwhile pidgins) by selecting particular features (including xenolectal ones) and helping them prevail over other alternatives and thus possibly reducing the extent of variation as a new norm emerges (DeGraff 1999a, 1999b, to appear). Creole children did this in the same way children everywhere normally contribute to both changes and stabilization of their target language. ${ }^{11}$

First language (L1) development is a protracted process and reaches maturity

\footnotetext{
${ }^{10}$ Insofar as the notion of 'idiolect' is metalinguistically significant, each one has a grammar to the extent that it is systematic, regardless of whether or not its system is identical with those of other idiolects in the relevant communal language or dialect. Like biological species, communal languages and dialects (as constructs of convenience) are internally variable (Mufwene 2001). Such variation can of course be more conspicuous in some varieties, such as incipient pidgins, than in others.

${ }^{11}$ This fact does not of course preclude current children from producing innovations that can spread within their language communities once they are past the child-language stage.
} 
after the speaker passes the critical period, i.e., by the time the speaker may be considered linguistically adult. Structures of English creoles are not identical with those of English child language, despite some similarities between them. For instance, English-speaking children do not produce the kinds of serial verb constructions attested in Saramaccan, for example, where a serial give conveys a dative function. Nor do they distinguish between the kinds of aspectual nuances attested in Gullah and Guyanese Creole, in which the preverbal marker don(e) (from nonstandard/colloquial English PERFECT verb done 'finish' rather than from the standard English past participle of do) conveys a different PERFECT meaning from the postverbal marker don, at least to those who use both constructions. While me done talk [mi d^n/don to:k/ta:k] simply means 'I have spoken', me talk done means more than that in these creoles, viz., 'I have said all I had to say and don't intend to talk again'.

Aside from the PROGRESSIVE construction with preverbal de, as in mi de taak 'I am talking’, Guyanese Creole also has a more specific, composite construction with preverbal de a, as in mi de a taak 'I am busy talking'. These are sophisticated grammatical distinctions which do not seem to have been innovated by Englishspeaking children. No parallel contrasts have been documented in English child language. Also, almost all Atlantic creoles have Predicate-Clefting, as in duh [də] talk he duh talk, illustrated here from Gullah and meaning 'he is/was really talking'. 
This can also be heard in nominalizations such as you shoulda hear da [də] talk he duh talk 'you should have heard how he was talking.' Like regular cleft constructions in English, this is definitely linguistic competence beyond child language, at least by age 3, the period that seems to have concerned Bickerton (1990).

If children innovated these structures in creoles, then they must have innovated them when they became linguistically adults, and we must wonder why their adult parents would have waited for them (the children) to innovate for the community when they (the parents) could have done so themselves. The answer can of course be similar to that provided by Judy Kegl and her associates about the role of children in the development of NSL, on which I comment above. However, the fact that only English creole-speaking children, but not their Anglophone counterparts, acquire these distinctions by the end of the critical period is a reflection of the influence that adult speech exerts on child language development. It also shows that, by the principle of least effort, creole children, like children everywhere, develop their idiolects from the PLD available to them from adult speech, even if this happens horizontally through the mediation of other children. We could also extrapolate that where the PLD lead to variable systems, children will also make allowance for variation in their idiolects. This extrapolation explains why the variation mischaracterized as “(post-)creole continuum” was not eradicated by children who participated in the development of creoles, not any more than any variation, or 
speech continuum, in any other language community would have been eliminated by children. $^{12}$

Thus, we should not confuse variation in the structures produced by adult L2speakers with the suggested inability on their part to develop a grammar or to innovate in the direction of a new full-fledged vernacular. ${ }^{13}$ Although several of their innovations must have not made their way into today's creoles, this is the normal case with innovations, which occur daily, in any speech community. The vast majority of them bear no impact on the communal language of a population. There is no compelling evidence for the conjecture that creoles owe to creations by children the structures that distinguish them from the European languages from which they have evolved. The case is even less convincing where the innovations can be related to features of substrate languages. The language bioprogram hypothesis (LBH) precludes children from transferring elements of substrate languages into the emergent creoles, because they had no prior knowledge of a language before the one they are misguidedly claimed to have created for their communities.

${ }^{12}$ For arguments against the decreolization hypothesis, see Mufwene (1994).

${ }^{13}$ Please note that pidgins have typically evolved in settings where their creators had their own vernaculars to speak outside their contacts with the populations they did not share a language with. This factor explains why expanded pidgins developed only in contact settings where speakers could not continue using their ancestral vernaculars with the other members of their new communities. Thus, creoles developed directly as vernaculars, because the members of the 
The fact that not all creoles have the particular constructions discussed here also suggests that, in the first place, there is no particular, uniform creole grammar that is replicated from one creole to another. It also shows clearly how futile it is to invoke children as the primary or exclusive makers of creoles — at least not at the child language stage - because these vernaculars contain some structures that have not been attested in child-language versions of the relevant European languages.

Most of the arguments for claiming that creoles were developed by children have had to do with the poverty, or absence, of inflections in these vernaculars. First, as argued by Slobin (2002), whether or not child language lacks inflections depends on what the target language is and how significant the role inflections is in it. DeGraff (2001) also shows that creoles are not as much deprived of inflections as has been claimed. In the very least, the old myth is not true of Haitian Creole.

What all these observations point to is that like language development among children, the development of creoles is subject to structural and ethnographic factors in the relevant linguistic communities. My own study of my daughter's child language (Mufwene 1999) suggests that the kinds of over-generalizations of regular morphological rules (such as goed for went and falled for fell) that occur when English-speaking children are 3 to 4 years old are transitional. At a younger age, my daughter had fell in contrast with falling and went in contrast with going, though there was no evidence that the pairs were grammatically related. While acquiring 
negation before age 3, my daughter also produced didn fell, didn took, didn saw, and didn woke, instead of didn't fall, didn't take, didn't see, and didn't wake, and she abandoned these deviations as soon as she became aware that adults around her do not typically use these past tense forms with didn't. Note, however, that the origins of the forms and constructions themselves are in adult speech, consistent with the Tomasello (2002) “cut and paste” model of L1-learning assumed here.

From a developmental perspective, children are more conformist and imitative than has been suggested, or claimed, in some child language literature, although they do indeed construct gradually the grammars of their idiolects by inference from the PLD that are accessible to them. They abandon their deviations quickly to conform to adult norms, including variation within those norms, as is evident from language communities anywhere, creole and non-creole alike. Given the way plantation settlement societies developed, we have no evidence for assuming that, linguistically and socially, slave children behaved differently from other children and did not just learn the vernaculars around them, as emergent as these were. Creole children must have contributed to the normalization through the selections they made from the feature pool of variants, thus determining (albeit nondeliberately, through the population-level distribution of their individual selections) how much xenolectal element would become part of the systems these vernaculars now have. The children never were the majority, nor did they form subcommunities of their own that were isolated from adult communities. There is no 
particular non-structural, ethnographic reason why they would have imposed norms of their own over those of the adults about them. They mostly perpetuated variants of the vernaculars that were already normalized or normalizing around them. We must recall that creole children were not in situations similar to those of Nicaraguan deaf children, because there always was a full-fledged language of the same modality around them, regardless of the extent of population-level variation in it.

According to Mufwene (2001), children actually slowed down the restructuring process during the development of creoles. This is because during the most prosperous period of the plantation colonies (i.e., the $18^{\text {th }}$ century in the Atlantic and Indian Ocean colonies, and the $19^{\text {th }}$ century in the Pacific), their populations grew more by importations than by birth. While the children "acquired" natively the local vernaculars that they heard around them and targeted, adult non-native speakers continued to restructure them, influencing them with their xenolectal features. There is still a lot to be learned about the dynamics of competition and selection among structural features of the European and substrate languages in the plantation settlement colonies (Mufwene 2001, 2002).

Still, we must remember that in this respect the difference between plantation societies and other communities is only a matter of degree. Variation is everywhere. Nowhere else have children been led by the circumstances to create a new language which would replace their parents' variable system. Slobin (2002) is correct again in 
holding adults as the primary innovators that should matter in language change and the development of creoles. Children play an undeniable role in helping determine which of those innovations become part of the communal language and which of the extant variants become recessive and may eventually die out of the ever-evolving language. So far we have no reason for assuming that the development of creoles is not the outcome of normal language change and diversification (Mufwene 2001). Thus, there is no empirical support for the LBH or the way Bickerton (1981f) hypothesized Universal Grammar (UG) to work in the development of creoles, crediting children almost exclusively with the emergence of their grammars.

\section{Do creoles tell us something about the evolution of language in mankind?}

Bickerton’s (1990) arguments that creoles and child language can give us insights about how language evolved in mankind are partly based on the assumption that ontogeny recapitulates phylogeny. They are also based on his hypothesis that creoles were made by children from erstwhile pidgins. As explained above, his position both lacks the support it would need from the socio-economic histories of creole-speaking societies and the logical justification that would make it even plausible. ${ }^{14}$ I focus here on

\footnotetext{
${ }^{14}$ The Hawai'ian plantations, which have figured prominently in Bickerton's hypothesis on the development of creoles, did not develop on the model of those of the Atlantic and Indian Oceans. To begin with, they started later (after the abolition of the slave trade and slavery), in the mid-19th century, and as a peripheral American settlement/exploitation colony. If they had a homestead phase at all, it must have been a (very) short one. In addition, the indentured laborers
} 
the ontogeny-recapitulates-phylogeny aspect of Bickerton's arguments and derive my support largely from Givón (1998), Li (2002), and MacWhinney (2002).

We must start with the fact that creoles' grammars show no evidence of having started from scratch or of having developed according to unmarked parametric settings of UG (cf. Bickerton 1981-1999). If these vernaculars had been produced by children, independent of the PLD available in their alleged grammar-less pidgin ancestors or, more realistically, independent of the data available in the colonial varieties of the European languages from which they have evolved, their grammars would not vary at all from one creole to another. ${ }^{15}$ Creoles' grammars do indeed

were not mixed, at least not as much as on the plantations of the Atlantic and Indian Oceans. They were brought successively from China, Japan, Korea, and, later, the Philippines, at intervals of more or less twenty years (Masuda 1995) and kept in separate work camps (Masuda, p.c., March 2002). Unlike the other plantation settlement colonies, the Hawai'ian setting was definitely propitious to the development of a pidgin as a reduced means of communication, because every ethnic group lived separately and used its own ethnic vernacular for in-group communication. Thus, a pidgin was needed for inter-group communication. The creole developed not on the plantations but in the city (Roberts 1998), where a more pervasive form of contact took place. It is not obvious from Roberts that the features that make Hawai'ian Creole distinctive from English or other English creoles from local English were innovated by children rather than by adults. Complicating the scenario is also the fact that Pidgin Hawai'ian was spoken on the islands before the plantations started and it seems to have contributed to the development of both Hawai'ian Pidgin and Creole Englishes.

${ }^{15}$ Independent of history, Bickerton's assumption that creoles’ grammars largely reflect UG with their parameters set in their unmarked options is more biased by typological markedness than by anything else. This is itself a function of a probability factor that need not be part of UG! 
vary, reflecting the extent of inheritance from the European language and/or that of substrate influence.

Contrary to what has been suggested at least by the earliest versions of Bickerton's LBH (1981, 1984), speakers do not develop grammars of their language varieties independent of the acquisition of their vocabularies. As suggested by Bolinger (1973), grammars are largely generalizations over the behaviors of individual lexical items. As a matter of fact, I submit that they are more projections on the part of the linguist, in their attempt to account for how we communicate (as we infer the existence of systems consisting of units and of combinatoric rules) than they exist of necessity. (See also Le Page \& Tabouret-Keller 1985:332.)

The connection between, on the one hand, creoles and, on the other, the relevant European and substrate languages is unmistakable once one compares them not so much with the standard varieties of European languages but with the nonstandard vernaculars actually spoken by the European yeomen and indentured servants with whom the non-European labor interacted regularly. Alternately, creoles' structures should be compared with those of the other vernaculars that have evolved from the koinés spoken by the proletarian European settlers, the typical founder populations

The Cartesian conception of UG suggests that all parametric options are equivalent and only particular linguistic systems would make some variants more, or less, marked than others. Thus makers of creoles are likely to have selected options that were less marked in the structural and ethnographic contact ecologies of their developments, not necessarily in UG (Mufwene 1991, 2001). 
of European colonies, with whom non-Europeans lived fairly intimately during the homestead phases.

One is hard-pressed to find in creoles any grammatical features that have not been selected from the nonstandard varieties of the relevant European vernaculars or in their substrate languages. There is in nonstandard English evidence of most of the features associated with English creoles, for instance, nominal plural with them, copula absence, periphrastic marking of tense-aspect (viz., unstressed habitual do [də] and does [dəz], stressed remote phase been [bIn] - though this occurs typically with a contracted have - continuative do/duh [də], perfect done, invariant relativization with what or a null complementizer, and reported speech introduced by say.) And there is similar evidence in Romance creoles (Chaudenson 1992, 2001). Even serial verb constructions have partial models in the relevant European languages. (See, for instance, Pullum 1990 regarding how they work in English.)

The key to understanding why creoles are different from their non-creole kin that evolved from similar colonial varieties of European languages is that language acquisition is a reconstruction process, which is sensitive to the variants in competition in the pool of features available to individual learners. The contact ecology of the appropriation of the European languages varied from one colony to another and from one period to another, which accounts also for why each creole is somewhat different from others that developed from what has been identified, for convenience sake, as more or less the same language. Moreover, linguistic features 
often get modified during the acquisition process, especially during L2 acquisition, as every learner analyses the PLD from which they develop their idiolects on their own, without particular explicit training. In the case of the development of creoles, congruence between structural features of the relevant European and substrate languages has been a critical factor, as clearly articulated recently in Corne (1999), Chaudenson (2001), Mufwene (2001), and DeGraff (to appear). Thus, as also argued by Chaudenson (1992, 2001) and Mufwene (2001), creoles have developed by gradual restructuring away from structures of the earliest colonial koinés of the relevant European languages in the direction of their basilects, which are actually the latest to have evolved. (See also Bickerton 1988.) None of this evolutionary process is remotely suggestive of how language evolved in mankind, originally from prelinguistic means of communication to protolanguage, concurrently with changes in the structure of human brain (Li 2002, MacWhinney 2002).

The relation of the development of creoles to language acquisition deserves some elaboration. We must first of all dismiss the myth that creoles have diverged from the relevant varieties of European languages because there was a break in the transmission of the latter to non-European groups on the plantations (e.g., Polomé 1983, Thomason \& Kaufman 1988). Not even the lexicon of creoles would have been inherited so predominantly from the relevant European languages (at least $90 \%$ on average) if there had been a break in the transmission of the latter. And one could not possibly imagine a group acquiring the vocabulary of a language, even under 
the conditions of sporadic contacts that produced pidgins, without getting some of the grammar associated with it. ${ }^{16}$

Admitting substrate influence does not entail ignoring numerous basic structural similarities (not due to any universals) which obtain between creoles and the relevant European languages from which they developed. The following randomly cited features will suffice to illustrate my point: 1) the phonologies of creoles largely reflect how the colonial varieties of the relevant European languages were spoken (e.g., the palatalized pronunciation of cat as $\left[k^{\mathrm{y}} a t\right]$ and pear as $\left[\mathrm{p}^{\mathrm{y}} \varepsilon\right]$ in Jamaican Creole); 2) the extensive use of adjectives and their prenominal use in English Creoles; ${ }^{17}$ 3) English creoles have definite articles where most substrate languages use a distal demonstrative;18 4) the postposed “determiner" la in Haitian Creole does not lack affinity with a similar morpheme which has similar morphosyntax, semantics, and pragmatics in nonstandard colloquial French varieties; and 5) the fact that only (Atlantic) English creoles use a form evolved from the verb say as a complementizer must have something to do with the fact that colloquial and non-standard English has more uses of say to report speech quotatively than French (Mufwene 1996). etc.

\section{An important question}

${ }^{16}$ This is where Bickerton's (1989) “lexical learning hypothesis” still falls short of an adequate account, as he suggests that children would be inventing on their own the grammatical properties of the lexical items they nonetheless took from their parents.

${ }^{17}$ We must bear in mind here the fact that the category 'Adjective' is hardly part of the grammars of many substrate languages.

${ }^{18}$ It is not evident that usage of the quantifier 'one' in the stead of the indefinite article is exclusive substrate influence. 
here that has typically been overlooked in the literature on the development of creoles is: Does "substrate influence" mean the same thing as "source of a structural feature?”

Language acquisition is of course imperfect, but, as noted by Lass (1997), imperfect replication is a normal condition in language transmission. Otherwise, there would be no language change in the first place, regardless of whether it is internally or externally motivated. Even in ethnographic ecologies where no contact of significantly different dialects or separate languages is involved, a language or dialect is usually appropriated by other speakers with minor modifications. Most of these coincide with variants already available in the communal language or dialect. However, sometimes others creep in, and/or the dynamics of the coexistence of variants in the population of speakers may change in such ways that some of the variants become stronger and may even drive others out. Such accretions of modifications are what linguists later identify as language change.

It is also useful to underscore the fact that "language transmission" and “language acquisition” are convenient misnomers for processes that are much more complex (DeGraff 1999a, 1999b, 2001, to appear; Mufwene (2001, to appear). Speakers of a language provides only the PLD to the learners. Nobody ever transmits an integrated linguistic system to other speakers, and no speaker ever passively inherits such a ready-made idiolect from previous speakers. Acquisition as a reconstruction process advances piecemeal, with the language learner developing 
competence in the target language only gradually. There is indeed some languagebuilding activity on the part of the learner, though it is not clear how the construction proceeds, i.e., whether or not the learner is focusing on developing a system or just trying to communicate successfully.

In the case of a child, misperception or inaccurate analogy with something previously learned may account for deviations. In the case of an adult learner, aside from these particular reasons, previously established linguistic habits (i.e., xenolectal influence) also account for such deviations. One thing is certain, the learner tries to speak like those speakers of the language that he/she targets, but he/she is not targeting a grammar or system in the way that a linguist would do by collecting a body of data, analyzing them, and producing an analysis of the system that can be inferred. McCawley's (1976) observation that a child should not be thought of as a mini-linguist can be generalized to say that a naturalistic language learner is not a linguist, especially since he/she approaches his/her communicative challenges bit by bit, without waiting until enough data have been collected. The process of generalizing from previously learned cases appear to be analogical.

Tomasello (2002) provides just the right kind of language development framework to account for this natural phenomenon of deviation or divergence from the target. His approach makes it possible for us to realize that the difference between deviations in L1 development and deviations in L2 development lies not in how these deviations happen but in the additional causes for the deviations in L2 
development. Naturally the additional causes increase the potential for deviations and produce in part what is known as non-native accent. Otherwise, we see in both cases a confirmation of Meillet's (1929) and Hagège's (1993) observation that language “acquisition" involves both inheritance from the target and recreation by the learner. The recreations involve innovations by the learner, regardless of whether they are made possible by analogies perceived in the target language itself or are caused by knowledge of another language. It is irrelevant whether at the communal level such innovations produce new features and divergences from the target communal language. When they do, we say that a language has evolved into another state, such as from Old to Middle English, or from English to creoles. As creoles appear to be normal outcomes of language appropriation by new populations under contact conditions in which substrate influence applies, Bickerton's (1990, 2000) claim that they can inform us about how language has evolved in mankind is not justified. If they do, it must be in respect to gradualness, competition and selection among variants, and the development of norms in populations of speakers. I return to these determinative factors of evolution below. 5. What creoles tell us about the evolution of language

We can now return to Givón’s (1998) thesis that the evolution of language in mankind is an adaptive process. In child language, the development of creoles, and other cases of language change, semantic and morphosyntactic innovations are especially exaptive, responding to (new) communicative needs of speakers beyond functions they 
have fulfilled in the target or earlier stages of the relevant language (Mufwene 2001). One thing that is especially noteworthy about creoles is that, despite their divergence from their non-creole kin, they have preserved both several features of the relevant European languages and complexities similar to those attested in several other languages spoken by modern humans.

If creoles had really developed from erstwhile pidgins, progressing from simpler to more complex grammatical structures, their development would share with the evolution of language as hypothesized by Givón the fact that every later stage exapted materials in the earlier stage. The closest analog to this evolution would be home sign language starting in part from the gestures used by their speaking parents and innovating on their own, gradually developing a communicative system with rudimentary grammar. However, this observation remains guarded, because Goldin-Meadow (2002) does not discuss whether such home sign language had developed into adult language. She does not discuss it as a population-level process similar to the NSL case, in which one can observe the development of a communal norm.

One particular characteristic that all the above cases of language development and evolution share is that they are all gradual processes. Givón (1998:105) submits that "human language (...) arose from the co-evolution of cognitive, neurological, communicative and socio-cultural patterns of pre-human hominids." Complementing this, Li (2002) and MacWhinney hypothesize that (proto-)language evolved from gestural means of communication (about 6 million years ago) to vocalizations and eventually to 
phonetic linguistic systems (between 200,000 and 50,000 years ago), concurrently with the emergence of the specific physiological and mental infrastructures required to support the complex-thought-processing capacity required to manipulate modern human languages. L1 development, from child to adult grammar, is also correlated with cognitive maturation/sophistication. The development of creoles and pidgins is similar only in being gradual processes.

Note that the problem pointed out by Slobin (2002) and Li (2002) remains, viz., that human infants today are born both with a brain infrastructure and in language ecologies that already distinguish them from our hominid ancestors. Therefore the ontogenyrecapitulates-phylogeny assumption does not apply at all. Modern children are typically born to social environments in which full-fledged languages are being spoken. The order in which they develop competence in their native languages, starting with basic and simple structures, reflect the maturation of their cognitive capacities. Although language “acquisition” is a reconstruction process, modern children cannot be credited with inventing a language in the same way that our hominid ancestors gradually invented language. If it is true that an individual's genotype determines his/her biological life trajectory, then, by the natural selection process that favored the modern human over other hominid alternatives, modern infants are born prewired to “acquire” the modern languages of the communities to which they are born. In this respect creole children are not different from other children.

The development of creoles and pidgins as communal languages also suggests 
another rarely discussed parallelism with the evolution of language in mankind as a population process, viz., inter-individual variation and the competition and selection that follow from it in the emergence of communal norms. We must remember that communal languages are only extrapolations from idiolects and language acquisition is an individual-based process (Mufwene 2001). Inter-individual variation is a consequence of the fact that no explicit teaching is involved in naturalistic language transmission and humans are not equally gifted in learning social skills. Current speakers only provide the PLD from which the learners can construct their idiolectal systems, which need not be identical with each other, though they are similar. As remarked by Chomsky (2000:100), “We need not assume shared pronunciations or meanings to account for [successful communication], any more than we assume shared shapes to account for people who look alike.”

We must, however, ask why inter-idiolectal differences among the members of a language or dialect community are not as great as they could be. Part of the answer lies in the Cartesian assumption that UG, also identified as the biological endowment for language, is the same for all modern humans. According to Chomsky (2000:30), “The only (virtually) 'shared structure' among humans is generally the initial state of the language faculty” (i.e., UG). Consistent with the fact that language development is gradual and protracted over years, another part of the explanation lies in the mutual accommodations that speakers make to each other, bringing their systems closer to each other, at least in respect to the structures of the utterances they produce. These mutual 
accommodations are part of what Mufwene (2001) characterizes as competition and selection, which operate in the feature pool to which all speakers make contributions. Like in evolutionary biology, competition is a convenient misnomer for the coexistence of variants associated with the same, or similar, functions in a system, in which they are not equally weighted. Selection refers to the advantage conferred to some of the variants that either prevail alone or are simply preferred (in more contexts) over other alternatives. In settings where several languages and/or dialects are spoken, competition and selection apply also to the different varieties (dialects and/or languages) in contact. We can say that they compete for speakers. It can reasonably be surmised that these principles, which are obvious in language acquisition and language change, must have also applied in the evolution of language in mankind. (Influences across languages are possible because languages are not selected wholesale with their features integrated, but rather because speakers develop their competences piecemeal, selecting features incrementally, often regardless of their sources.)

Notwithstanding the fact that ecology rolls the dice to resolve competition, even in maintaining variation, we can imagine that spoken language was generally favored over signed language for precisely some of the reasons articulated by Givón (1998:89), such as the following: 1) "freeing the hands and the body (...) so that communication may now proceed simultaneously with manual activities, and can in fact support them”; and 2) "transcending the visual field" so that "auditory-oral communication may proceed in the 
dark, in thick bush, over physical barriers that prevent eye contact.”19

Structural differences and typological variation among the world's languages are a reminder of the variation that must have obtained locally and across distances in the evolution from gestural to linguistic communication in mankind. It is not farfetched to speculate that competition and selection must have played an important role in reducing the range of wave frequencies used by humans in their phonetic inventories. They must also have played a role in leading members of individual communities to agree on the number of the specific phonemes they use, on the range of variation in the production of these phonemes, and on the way they combine them into longer meaningful utterances (words and sentences). Thus, they can tell which variants have normally been generated by their communal language and which ones have not.

Given the ways in which incipient pidgins dispense with much of the structural systems of the languages from which they evolved, we can surmise that they preserve the components of language architecture that are the most robust and perhaps the most deeply entrenched. ${ }^{20}$ For instance, they remain languages because

${ }^{19}$ In evolutionary terms, sign language (not to be confused with communication by gestures) has indeed not been eliminated; it has remained statistically an alternative to spoken language.

${ }^{20}$ Wimsatt (forthcoming) argues that the structures that are phylogenetically the most deeply entrenched are also the most resistant to change in biological and cultural systems, including research paradigms. See also Wimsatt (2000). 
they remain discrete and combinatorial spoken systems (relying on limited phonetic inventories), make use of lexical items, and preserve the symbolic referential function of language. ${ }^{21}$ Not having a complex grammar accounts for why pidgins are said to rely heavily on pragmatic context for rich semantic interpretation, which seems to support Givón’s (1998:92) hypothesis that grammar has provided “speeded-up, more automated language processing,” making full-fledged languages less dependent on pragmatic context.

From the point of view of child language, one can argue that modern human infants are already preprogrammed for symbolic communication, in the spirit of Chomsky's UG (though details remain to be worked out) and that learning a native language entails starting with those aspects of communication that are phylogenetically the most deeply entrenched as determined in part by the state of the infant's cognitive capacity. However, we must remember that, unlike our hominid ancestors, modern children do not normally develop their own separate communal languages from particular gestural means of communication nor embryonic languages, and independent of what the adults who nurture them do to communicate. Thus the above observations do not lead to the traditional conclusion that ontogeny recapitulates phylogeny. There is certainly nothing in the

\footnotetext{
${ }^{21}$ See Deacon (1997) for similar ideas about features that distinguish the earliest forms of human languages from communication systems in other animal species, especially the significance of symbolism.
} 
development of creoles and pidgins that comes close to supporting such a claim.

It is also noteworthy that the structural heterogeneity of creoles that has aptly been characterized in the literature as a continuum largely reflects the fact that those who developed them were not engaged in the process as a team. Rather, each one of them was personally trying to communicate and in the process developed their own individual idiolect, though they exerted mutual influences on each other — which accounts for the family resemblance that obtains among the idiolects of a communal language. The divergence of creoles from the relevant European languages is simply a selective accumulation of divergences that took place convergently in the idiolects of speakers, just what happens in any case of language evolution. We can surmise that our hominid ancestors who developed protolanguage(s) did not proceed like a team either, as much as members of every community must have wanted to communicate successfully with each other and converged their systems through mutual accommodations. ${ }^{22}$ There must have been variation at all stages of language evolution, which fostered competition and selection, hence continuous evolution. Thus, at every stage of the evolution of mankind, speakers modified the language they learned from the preceding

\footnotetext{
${ }^{22}$ This communal behavior is undoubtedly cooperative but it differs from that of a team. In the latter case, the goal of the activity, the roles of the participants, and the rules of cooperation are explicitly articulated. The participants are often required to behave altruistically in the interest of the team. With successful communication as the goal, linguistic behavior is not altruistic.
} 
“generation of speakers” (regardless of age group), children and adults all engaged in the process.

\section{References}

Alleyne, Mervyn C. 1980. Comparative Afro-American. Ann Arbor: Karoma.

Baker, Philip. 1993. Australian influence in Melanesian Pidgin English. Te Reo 36.3-67.

Bickerton, Derek. 1981. Roots of language. Ann Arbor: Karoma.

Bickerton, Derek. 1984. The Language Bioprogram Hypothesis. Behavioral and Brain Sciences 7.173-221.

Bickerton, Derek. 1988. Creole languages and the bioprogram. In Linguistics: The Cambridge survey. Volume 2: Linguistic theory: Extensions and implications. Frederick J. Newmeyer, ed., 268-84. Cambridge: Cambridge University Press.

Bickerton, Derek. 1989. The lexical learning hypothesis and the pidgin-creole cycle. In Wheels within wheels: Papers of the Duisburg symposium on pidgin and creole languages, ed. by Martin Pütz \& René Dirven, 11-31. Frankfurt am Main: Verlag Peter Lang.

Bickerton, Derek. 1990. Language and species. Chicago: University of Chicago Press.

Bickerton, Derek. 1999. How to acquire language without positive evidence: What acquisitionists can learn from creoles. In DeGraff, ed., 49-74.

Bickerton, Derek. 2000. How protolanguage became language. In The evolutionary emergence of language: Social function and origins of linguistic form, ed. by Chris 
Knight, Michael Studdert-Kennedy, and James R. Hurford, 264-284. Cambridge:

Cambridge University Press. Bloomfield, Leonard. 1933. Language. New York: Holt, Rinehart and Winston.

Bloomfield, Leonard. 1933. Language. New York: Holt, Rinehart and Winston.

Bolinger, Dwight. 1973. Getting the words in. In Lexicography in English, ed. by Raven McDavid, Jr. et Audrey Duckert, 8-13. New York: New York Academy of Science. Bolton, Kingsley. 2000. Language and hybridization: Pidgin tales from the China coast. Interventions, 5, 35-52.

Bolton, Kingsley. 2002. Chinese Englishes: From Canton jargon to global English. World Englishes, 21, 181-199.

Chaudenson, Robert. 1979. Les créoles français. Paris: Fernand Nathan.

Chaudenson, Robert. 1992. Des îles, des hommes, des langues: essais sur la créolisation linguistique et culturelle. Paris: L'Harmattan.

Chaudenson, Robert. 2001. Creolization of language and culture. London: Routledge.

Chomsky, Noam. 1986. Knowledge of language. New York: Praeger.

Chomsky, Noam. 2000. New horizons in the study of language and mind. Cambridge: Cambridge University Press.

Comrie, Bernard. 2000. From potential to realization: An episode in the origin of language. Linguistics 38.989-1004.

Corne, Chris. 1999. From French to Creole: The development of new vernaculars in the French colonial world. London: University of Westminster Press. 
Deacon, Terrence W.1997. The symbolic species: The co-evolution of language and the brain. New York: W.W. Norton \& Co.

DeGraff, Michel. 1999a. Creolization, language change, and language acquisition: A Prolegomenon. In DeGraff, ed., 1-46.

DeGraff, Michel. 1999b. Creolization, language change and language acquisition: An epilogue. In DeGraff, ed., 473-543.

DeGraff, Michel, ed. 1999. Language creation and language change: Creolization, diachrony, and development. Cambridge, MA: MIT Press.

DeGraff, Michel. 2001. On the origin of creoles: A Cartesian critique of 'neo'-Darwinian linguistics. Linguistic Typology 5.213-310.

DeGraff, Michel. to appear. On creole genesis and language acquisition: Some methodological and theoretical preliminaries. In Handbook of pidgin and creole linguistics, ed. by John Singler and Silvia Kouwenberg.

Givón, T. 1998. On the co-evolution of language, mind, and brain. Evolution of communication 2.45-116.

Givón, T. \& Bertram F. Malle, eds. 2002. The Evolution of Language out of PreLanguage. Amsterdam: John Benjamins.

Goldin-Meadow, Susan. 2002. Getting a handle on language creation. In T. Givón \& Bertram F. Malle, eds, 343-374.

Hagège, Claude. 1993. The language builder: An essay on the human signature in linguistic morphogenesis. Amsterdam: John Benjamins. 
Hagège, Claude. 2001. Creoles and the notion of simplicity in human languages.

Linguistic Typology 5:167-175.

Jackendoff, Ray. 2002. Foundations of language: Brain, meaning, grammar, Evolution. Oxford: Oxford University Press.

Jespersen, Otto. 1922. Language: Its nature, development and origin. London: Allen \& Unwin.

Keesing, Roger M. 1988. Melanesian Pidgin and the Oceanic substrate. Stanford: Stanford University Press.

Kegl, Judy \& John McWhorter. 1997. Perspectives on an emerging language. In Proceedings of the Twenty-Eighth Annual Child Language Research Forum, ed. by Eve Clark, 15-38. Stanford, CA: Center for the Study of Language and Information.

Kegl, Judy, Ann Senghas, \& Marie Coppola. 1999. Creation through contact: Sign language emergence and sign language change in Nicaragua. In Michel DeGraff, ed., 179-237.

Kihm, Alain. 2002. Langues créoles et origine du langage: état de la question. Langages 146.59-69.

Lass, Roger. 1997. Historical linguistics and language change. Cambridge: Cambridge University Press.

Le Page, R.B. \& Andrée Tabouret-Keller. 1985. Acts of Identity: Creole-based approaches to language and identity. Cambridge: Cambridge University Press.

Li, Charles N. to appear. On the evolutionary origin of language. In Mirror neurons and 
the evolution of brain and language, ed. by M. Stamenov \& V. Gallese. Amsterdam: John Benjamins.

MacWhinney, Brian. 2002, The gradual emergence of language. In T. Givón \& Bertram F. Malle, eds., 233-263.

Masuda, Hirokuni. (1995). TSR formation as a discourse substratum in Hawaii. Journal of Pidgin and Creole Languages, 10, 253-288.

McCawley, James D. 1976. Some ideas not to live by. Die neueren Sprachen 75. 151-65.

Meillet, Antoine. 1929. Le développement des langues. In Continu et discontinu, 119ff.

Paris: Bloud \& Gay. Reprinted in Meillet 1951:71-83.

Mufwene, Salikoko S. 1991. Language genesis and human evolution. (Review article on Bickerton 1990.) Diachronica 8.239-254.

Mufwene, Salikoko S. 1994. On decreolization: The case of Gullah. In Language and the social construction of identity in creole situations, ed. by Marcyliena Morgan, 63-99. Los Angeles: Center for Afro-American Studies.

Mufwene, Salikoko S. 1997. Jargons, pidgins, creoles, and koinés: What are they? In The structure and status of pidgins and creoles, ed. by Arthur Spears and Donald Winford, 35-70. Amsterdam: John Benjamins.

Mufwene, Salikoko S. 1999. The language bioprogram hypothesis: Hints from Tazie. In DeGraff, ed., 95-127.

Mufwene, Salikoko S. 2000. Creolization is a social, not a structural, process. In Degrees of restructuring in creole languages, ed. by Ingrid Neumann-Holzschuh and Edgar 
Schneider, h65-84. Amsterdam: John Benjamins.

Mufwene, Salikoko S. 2001. The ecology of language evolution. Cambridge: Cambridge University Press.

Mufwene, Salikoko S. 2002. Competition and selection in language acquisition. Selection 3.45-56.

Mufwene, Salikoko S. to appear. Multilingualism in linguistic history: Creolization and indigenization. In Handbook of bilingualism, ed. by Tej Bhattia and William Ritchie. Blackwell.

Mühlhäusler, Peter. 1997. Pidgin and creole linguistics, expanded and revised edition. London: University of Westminster Press.

Paul, Hermann. 1891. Principles of the history of language. London: Longmans, Green, and Co.

Polomé, Edgar. 1983. Creolization and language change. In The social context of creolization, ed. by Ellen Woolford and William Washabaugh, 126-36. Ann Arbor: Karoma.

Pullum, Geoffrey K. 1990. Constraints on intransitive quasi-serial verb constructions in Modern Colloquial English. In When verbs collide: Papers from the 1990 Ohio State Mini-Conference on Serial Verbs, ed. by Brian D. Joseph \& Arnold Zwicky, 218-239. Department of Linguistics, Ohio State University.

Roberts, Sarah Julianne. 1998. The role of diffusion in the genesis of Hawaiian Creole. Language, 74, 1-39. 
Sankoff, Gillian. 1984. Substrate and universals in the Tok Pisin verb phrase. In Meaning, form, and use in context: Linguistic applications, ed. by Deborah Schiffrin, 104-19. Washington, DC: Georgetown University Press.

Sankoff, Gillian, and Penelope Brown. 1976. The origins of syntax in discourse: A case study of Tok Pisin relatives. Language 52.631-66.

Schuchardt, Hugo. 1914. Die Sprache der Saramakkaneger in Surinam. Amsterdam: Johannes Müller.

Senghas, Anne \& Marie Coppola. 2001. Children creating language: How Nicaraguan Sign Language acquired a spatial grammar. Psychological Science 12.323-328.

Singler, John Victor. 1988. The homogeneity of the substrate as a factor in pidgin/creole genesis. Language 64:27-51.

Slobin, Dan I. 2002. Language evolution, acquisition, diachrony: Probing the parallels. In T. Givón \& Bertram F. Malle, eds., 375-392.

Thomason, Sarah G. \& Terrence Kaufman. 1988. Language contact, creolization, and genetic linguistics. Berkeley: University of California Press.

Tomasello, Michael. 2002. The emergence of grammar in early child language. In T. Givón \& Bertram F. Malle, eds., 309-328.

Wimsatt, William C. 2000. Generativity, entrenchment, evolution, and innateness. In Biology meets psychology: Constraints, connections, conjectures, ed. by V. Hardcastle, 139-179. Cambridge, MA: MIT Press. 